\title{
A Complicated Welcome: Social Workers Navigate Policy, Organizational Contexts and Socio-Cultural Dynamics Following Migration to Canada
}

\author{
Marion Brown ${ }^{1}$, Annie Pullen Sansfacon ${ }^{2}$, Stephanie Ethier ${ }^{2} \&$ Amy Fulton ${ }^{3}$ \\ ${ }^{1}$ School of Social Work, Dalhousie University, Canada. \\ ${ }^{2}$ Universite de Montreal, Montreal, Canada. \\ ${ }^{3}$ Unviersity of Calgary, Calgary, Canada. \\ Correspondence: Marion Brown, School of Social Work, Dalhousie University, Canada.
}

Received: October 29, 2014

doi:10.11114/ijsss.v3i1.569
Accepted: November 13, $2014 \quad$ Available online: December 11, 2014

URL: http://dx.doi.org/10.11114/ijsss.v3i1.569

\begin{abstract}
Canada prides itself on a reputation of being a welcoming and inclusive country, promoting a collective pride in upholding a multicultural mosaic wherein a rich diversity of ethnicities, cultures and religions co-exist. A priority of the Canadian federal government is the attraction and retention of skilled foreign workers into the labour market, and social workers have been targeted for this government initiative. Alluring though this ideal picture may be, the experiences of forty-four migrant social workers who undertook their social work education outside Canada and currently practice social work in Canada suggest significant barriers on the levels of policy, organizational context and socio-cultural dynamics. On the level of policy, participants navigated processes for immigration, recognition of foreign credentials, and licensure with the provincial regulatory body. On the level of organizational context, participants faced a range of challenges in securing social work employment. On the level of socio-cultural dynamics, participants detail the many interactive subtleties experienced as they sought to 'fit in' in order to connect with their new colleagues and communities. Analysis draws on the concepts of institutional and embodied cultural capital as the means though which social status is differentially available for these migrant social workers, based on the ascribed value of their citizenship characteristics, educational preparation, and practice experience. These forms of capital facilitate mobility by enabling access to opportunities and the tools to acquire status and entry to a particular class, that of the social work practitioner in Canada.
\end{abstract}

Keywords: acculturation, adaptation, migration, professional practice, social work

\section{Introduction}

Canada is promoted as a land of opportunity, with its natural beauty purportedly matched by the generosity of its people. Since 1994, Canada has been ranked in the top ten places to live in the world, and in 2013 it placed third in the global 'better life index', recognized for its comfortable standard of living, low mortality rate, solid education and health systems, and low crime rate (Organization for Economic Cooperation and Development [OECD], 2013). It is a promising option for migrant professionals looking to leave their home countries for a variety of reasons related to social, political and economic conditions. This paper reports on the experiences of forty-four social workers who undertook their social work education outside Canada and migrated to Canada with the intent of continuing to practice social work. We bring analysis to three key areas experienced as problematic: policy, including immigration, recognition of foreign credentials, and registration with the licensing body; organizational context, including issues related to the search for employment and process of hiring; and socio-cultural dynamics, the more subtle relations required to 'fit in' and feelings of 'difference' in relation to one's colleagues. The findings for each of these are discussed in detail below, drawing on Bourdieu's concept of cultural capital (Bourdieu, 1986).

\section{The Context of Immigration to Canada}

Canada prides itself on a reputation of being a welcoming and inclusive country, promoting collective pride in a multicultural mosaic wherein a diversity of ethnicities, cultures, and religions co-exist. It is a country that often enjoys positive international assessment, with its reported comfortable standard of living, solid social programs, mix of urban and rural lifestyles, vast and spectacular natural beauty, and people often considered polite and consensus driven. It is 
also a country with a growing density divide between urban growth and rural out-migration, an aging demographic, and regional variability in population growth (Statistics Canada, 2012). This scenic land of opportunity has evident appeal to immigrants leaving their countries of origin for a variety of social, economic, and political reasons.

The Canadian government, reciprocally, views the newcomer to Canada as providing an answer to sustaining the country's demographic and economic growth. Under both Liberal and Conservative party leadership, the Canadian government has sought to liberalize its labour and trade markets through policies including the North America Free Trade Agreement and programs such as those designated for temporary foreign workers, skilled trade workers, and professional immigrants (Citizenship and Immigration Canada, 2014). These efforts are considered to have been successful. For example, the Migrant Integration Policy Index determined that Canadian immigrant workers and their families benefit from the third best integration policies in the 31 countries, citing specific government efforts toward improving equal access in education and labour (Migration Integration Policy Index III, 2011). The International Migration Outlook, published in 2013 by the OECD, cites immigration as accounting for two-thirds of Canada's population growth of $1.2 \%$, primarily in the age bracket of 20-44 years, which is otherwise in decline. It is this cohort which contributes significantly to the labour force, grows families, buys homes, and forms the basis of taxation revenue (OECD, 2013). Canada reached a record high of 281,000 new permanent residents to Canada in 2010, and followed with 249,000 new permanent residents to Canada in 2011 (OECD, 2013). Further, employment for foreign-born Canadian in 2012 earned Canada the ranking of third highest in the OECD (OECD, 2013).

This government priority continues. Recently, the federal government announced a new program to be in place by January 2015, touted to be a 'fast and flexible system of economic immigration' (Gignac, 2013), through which skilled immigrants who want to move to Canada will be matched with Canadian employers looking to fill job vacancies. Modelled after similar systems in Australia and New Zealand, a bank of skilled immigrants will be created, which employers can access and search, privacy laws withstanding. When a match has been made the immigrant will be invited to apply for permanent residence. Immigration minister Chris Alexander promises that this system will result in a 'workforce that will make itself at home in a Canadian economy much more quickly' (Gignac, 2013).

Internationally educated social workers are included in these trends, through both federal and provincial initiatives. For example, the social work profession is included as one of the twenty nine eligible occupations on the "Federal Skilled Worker' recruitment policy list (Healy \& Huegler, 2012), and Chapter 7 of the Agreement on Internal Trade, 'Mutual Recognition Agreement on Labour Mobility for Social Workers in Canada' has been implemented (Canadian Information Centre for International Credentials, 2007). Further, the Government of Quebec has enacted a Mutual Recognition Agreement between Quebec and France for the qualifications of social workers in professional employment (Canadian Information Centre for International Credentials, 2007). These policies and entities support the mobility of social workers both from overseas to Canada and across the country's provinces and territories.

Further painting an enticing picture for migrant social workers, the International Association of Schools of Social Work (IASSW) and the International Federation of Social Work (IFSW), joined together to publish a document which provides an international definition of social work as well as global standards for ethics and education in social work (IASSW/IFSW, 2012; 2014). These documents aim to balance universal understandings and contextual specificities, and provide a point of reference for social workers on the move, given they set international expectations in terms of knowledge, theories and values of social work (Spolander, Pullen Sansfaçon, Brown \& Engelbrecht, 2011). These global standards are recognized as providing a common basis of expectation in relation to social work practice worldwide. Its existence acknowledges both the transnational mobility of social workers and the impact of global issues and dynamics on local practice (Lyons, 2006).

Given the reach of globalization and the development of policies and multi-lateral agreements, labour mobility in social work, both at national and international levels, is increasingly popular. Indeed, this cluster of considerations seems perfect: the idealized Canadian landscape and welcome declining and aging population need for demographic and economic input favorable immigration policies social worker-specific labour mobility policies an internationally endorsed set of global standards for the profession. Alluring though this picture may be, research examining the experiences of forty-four migrant social workers who undertook their social work education outside Canada and currently practice social work within Canada suggest significant barriers on the levels of policy, organizational context and socio-cultural dynamics. Analyses of findings regarding personal and professional adaptation across borders suggest that the idealized Canadian welcome is a complicated one. From the level of policy, to organizational context, to socio-cultural dynamics, migrant social workers experience a tension between a discourse of possibility and opportunity surrounding life and work in Canada and material constraints in bureaucratic processes and finding a fit in the social work profession in Canada. 


\section{Methodology}

This paper presents findings from a qualitative study with forty-four participants who had completed their social work degrees in Australia, India, Philippines, Colombia, Spain, Liberia, New Zealand, Finland, France, Venezuela, Germany, United Kingdom, Romania, United States, Israel, Nigeria, Lebanon, South Africa, Netherlands and Ukraine since 2002. Grounded theory methods guided analysis of the individual interviews, given that this is a largely under-theorized field of study: with the exception of a team of researchers in the United Kingdom (see Hussein, Manthorpe \& Stevens, 2010; 2011) and in New Zealand (see Bartley, Beddoe, Fouché \& Harington, 2012; 2013) the experiences of social workers who migrate, their professional adaptation processes, and the many changes in perception they undergo while adapting to new cultural and organizational contexts, have not been well conceptualized and theorized in the literature (Pullen Sansfaçon, Brown \& Graham, 2012).

Participants were recruited through social work networks, including professional association newsletters, regulatory body list serves, and posters in agencies. Snowball sampling was also an effective method for extending recruitment methods. Three urban sites of Calgary, Montreal and Halifax were selected, each for their distinct regional trends in attraction of newcomers. However, as the study progressed, the pool of potential participants proved limited in Calgary and Halifax, thus the catchment area extended to southern Alberta in the west, and Nova Scotia and Prince Edward Island in the east. Participants chose whether to speak English or French in their interviews.

Data were collected for three years, between 2011 and 2014, through individual in-depth interviews with a focus on education and experiences in country of origin and in Canada, experiences of immigration and of finding social work employment in Canada, and the transferability of values, knowledge and skills between country of origin and Canada. Participants were also asked about professional dynamics with clients, colleagues and organizational contexts, in comparison with their work in their countries of origin. The theoretical conceptualization of the study (Pullen-Sansfacon, Brown \& Graham, 2012) and analysis of the factors that facilitated and mitigated adaptation, in both professional and personal terms (Pullen-Sansfacon, Brown, Graham \& Michaud, 2014) are published elsewhere. The study was granted ethical approval by University of Calgary, Université de Montreal and Dalhousie University for the period $2011-2015$.

Consistent with grounded theory methods, no extant concepts were taken from the literature; the coding structure and team analysis was generated 'from the ground up', directly from the data. Interviews were coded line by line in each site to capture the meaning and relevance of each passage of text per region. The research team then engaged in analysis across sites, moving to segments of text and deepening the analysis to move from the grounded codes to categories of codes, and finally abstracting to robust themes that are mutually exclusive. The emerging theory of adaptation is one of an interaction among the personal, the professional, and the context: one's attributes and characteristics are brought to bear on the values, aspirations, tensions, ideological and practical challenges of social work practice, and both play out in the agency context, the material structure within which relations with clients, colleagues, supervisors and the broader public are enacted (Pullen-Sansfacon \& Brown, forthcoming).

\section{Findings}

This paper brings forward the findings related to the process of navigating the Canadian cultural context, from levels of formal policy to organizational structures, to socio-cultural dynamics of the workplace. On the levels of immigration, credential recognition, and licensure, to securing employment, immigrant social workers face several systemic barriers to their adaptation.

\subsection{Canadian Immigration Policies}

The first set of policies with which newcomer social workers grapple are Canadian immigration policies, often researching them from abroad while planning for their move. While detailed with regard to purpose and process on the federal government website (Citizenship and Immigration Canada, 2013) frustrations remain regarding their clarity and user-friendliness. It is clear from these data that finding one's way through the immigration process takes fortitude, self-advocacy, perseverance, and patience. This combination is captured in a summary statement by a participant from England, who says,

My experience has been is if you come into Canada... then you need to put your helmet on and fasten your seatbelt....It's not for the faint heart, the process, and you gotta stick with it. (England-2)

Detailing specific aspects of the process, the following participant highlights accessibility:

The process of immigration is extremely difficult. The Department of Immigration has a website and an email address. They do not have a phone number, so you can't call anyone and ask questions. Everything you need to know you need to find out off the Internet. And when you email a question to them it may be several days before you get a response. And then it says, 'look at the website'. (Australia-1) 
Some commented on the variability among the criteria, such that it was 'really hard to know what applies to you and what doesn't' (India). The amount of detail required was daunting as well, for example wanting 'every address I'd had since I was eighteen.... every place I've stayed and every job I've had' (Lebanon).

Several participants described the circular process of needing a job offer to get residency, and yet needing residency to get a job offer. A participant from Germany sums up her experience in saying, ' $[\mathrm{I}$ saw $]$ through immigration their skilled worker program, I thought I can go through that. But then, I need a job first to get to the program. But without the work permit no-one would hire me.'

Some wonder if the cumbersome process is intended to dissuade newcomers from seeking residence in Canada, like the participant from Spain who said 'do they even ever want us here?' Indeed, there is a paradox in the approach of the federal government, in that a co-existing policy of Citizenship and Immigration Canada (CIC) is clear that employers are required to undertake recruitment efforts to hire Canadian citizens and permanent residents before offering a job to 'foreign workers' (Citizenship and Immigration Canada, 2014). The priorities of the federal government appear at a cross roads, trying to manage the tension of hiring Canadian citizens first, which is important in a country where the average unemployment is at $6.9 \%$, yet ranges across the provinces from $4.5 \%$ in Saskatchewan to $11.8 \%$ in Prince Edward Island (Statistics Canada, March 2014), and also building its population and economic base through the attraction of skilled professionals to this country.

\subsection{Recognition of Foreign Credentials}

Recognition of foreign credentials is the next level of policy navigation for newcomer social workers, a process through which assessment is made regarding the degree of equivalence between an international social work degree and a Canadian social work degree. Given that social work is a regulated profession in Canada, this is required in order to be licensed by the regulatory body for each province. While recognition of foreign credentials is not under the federal government's mandate, either by law or by policy of CIC, the foreign credentials referrals office was established by CIC to provide information to immigrants (Citizenship and Immigration Canada, 2013).

The Canadian Association of Social Workers (CASW) is the mediating body for the provincial regulatory bodies that do not facilitate recognition of foreign credentials; only British Columbia and Quebec undertake their own assessment (Pullen Sansfaçon, 2010). Findings from our study suggest that there are inconsistent criteria, lengthy time delays, and general frustration with the process of evaluation of one's credentials earned at a university or college outside Canada.

I didn't really know where to start. I tried to figure it out, I tried to contact them and figure out what I needed then, if I'd missed something in my education. ... But they wouldn't give me any information on what I missed and the message I got at that point....was to register into a BSW program and then see what credits I would get, like that I already have, that I didn't have to retake and then just take whatever was left, kind of thing. And so I tried that. I tried to register at the [university] and they said I couldn't register because I already had a BSW. (Netherlands-1)

I remember feeling disgusted that I'd paid ... in excess of three hundred dollars for a one page letter which was really quite unclear in the message or what it was actually saying to me....The letter from the Canadian Association of Social Workers outlined that the social work courses that I'd completed at university were equivalent to Canadian standard and my practice placement or practicum was equivalent to Canadian standard. But they stated one line in the letter that 'regrettably...due to insufficient liberal arts courses studied, there is no equivalence to a Canadian BSW'. (England -1)

It took four months. Four months and they wanted an original of all my degrees and certificates, which I can understand because some people want to fake it, but four months! For God's sake I went for four months before my family could eat. You know, I just found that outrageous. (Liberia)

There were also reports of errors in the review of credentials, for example this participant from England:

... the letter I got with my accreditation said, 'this is to certify blah, blah, blah, equivalent of a Canadian' and then it said 'MSW' and then in brackets 'without thesis'. I didn't understand why, because I did a thesis so I called them and they said they'd made a mistake. They re-looked at my things, apologized, sent me a letter of apology and a new letter that said 'with thesis'. (England-3)

These difficulties in getting foreign credential recognized are also echoed by participants from France. While the unique France-Quebec agreement should 'facilitate and accelerate the acquisition by people in France and Québec of a permit to practise a profession' (Gouvernement du Québec, 2013), several participants who established themselves in Montreal after moving from France experienced delays and challenges in getting their credentials recognized. A participant from France who immigrated to Montreal illustrates:

I did not expect to have to wait 6 months because I had checked on the [Quebec] professional association of social 
workers' website and they did not explain at all the way to proceed or that it could take as long. I thought it would be much simpler. I was a little disappointed when I arrived here as I had to work as a [unqualified] social care practitioner. (France)

In addition, frustration was reported when there was lack of communication, or circularity, between the Canadian Association of Social Workers and the provincial bodies:

I spoke with the [provincial body], who said to ... have [the degrees] accredited by the Canadian association so I did that.... When I then applied to register with the [provincial body], they said 'oh we need the transcripts and everything' and I said 'you know it was really kind of just a bit messy trying to get them from England, could you not get them from the Canadian [Association]?' and they said 'we have no connection with them'. And I was like 'hang on, you just told me I couldn't register with you until I was approved by the Canadian [body]... so surely you have, like, one call you could make!' (England-3)

These data align with the challenges documented in several countries (Bartley et al. 2012; White 2006; Fang, 2012) that the difficulties faced in obtaining degree recognition are among the first challenges that migrant social workers encounter in the new country. After working through immigration processes and assessing the equivalence of international social work education to Canadian social work education, next comes securing the license to practice as a registered social worker.

\subsection{Social Work Licensure}

Securing a license to practice social work is a rite of passage for social workers seeking to work in the field in Canada. This process, too, is experienced as cumbersome and lengthy, sometimes with mixed messages regarding what is required for the license. Self-advocacy was a central strategy for moving through the process, as exemplified by these participants:

It took a couple of months in order to gather all that information and go back and forth and respond to 'OK, we need this now'.... I'd say a few months, but ...I think that was just me being a pest and continuing to call people and say, 'did you do this yet? Did you do it yet?' I can be a little persistent sometimes. (United States -1)

If you're not registered, if you're not a candidate, you're not eligible for any social work job....Well, I, I, started to learn how things work in North America, so I started bucking a lot. And being resistant. And one thing that I learn is that in [province], specific thing to [province], it doesn't matter what you know. It matters who you know. So I started pushing, asking the right questions, and pushing the right way and eventually I got to be a candidate. (Netherlands-1)

Given that licensure is a central requirement for securing social work positions, there were concerns with the amount of time the process took:

I sent my registration package and I was told I would get an answer in 5 days - an official answer, letter format. Nobody called me so I kept calling after one month, after the second month. I was always told that the Registrar was out of her office, she's in the workshop, she's on vacation, she's here and there. I did not hear from them at all so finally I contacted them again. I said if ...they want me to do some extra things like courses or approve credentials then I am definitely willing to do whatever it takes. So finally they wrote me back an email saying that I will have to prove some of my courses from Romania, that I took ethics in social work and social organization courses.... I managed to translate that, to notarize it and then to send it to the [regulatory body]....They finally came back to me after another long 2 month wait. They told me that they would register me provisionally. (Romania)

It was frustrating that my application to the [provincial body] got lost in the post and I had to re-send a wad of paper. Then I had to wait three weeks for to have a meeting with them, they requested that I had to have a meeting with them in [city]. So I had to travel there for a meeting to meet with the Board for an oral examination which I found peculiar....because I sent all the pieces of paper that they asked for and more. (England-1)

Moreover, within the grapevine of newcomer social workers, participants heard of variability in the requirements to obtain the license to practice.

... Social workers from the Philippines that I did work with, they were either asked to earn credit hours [in a practicum], some credit hours in class, or both. In my case, I wasn't asked or required by the [regulatory body]. (Philippines)

While there was frustration expressed by many, this was also often mixed with resigned acceptance:

I'm a qualified social worker with a degree in social work and I had to meet with them, was a requirement to meet with them for registration....I had a phone call from the Registrar in the week afterwards to let me know that ... 
they were impressed by what I had to say and that they liked me. I found that amusing. But I just kind of put it to bed and thought well, this is how they do in [province]. You've just gotta do it. (England-2)

Issues of clarity, process delays and additional practice hours constitute significant challenges to finding employment in the field of social work because in each province the profession has been granted protected title under legislation. The findings of this study align with research undertaken in New Zealand, that in addition to the recognition of their skills, candidates need to demonstrate evidence of their qualifications for local practice (Beddoe, Fouché, Bartley \& Harington, 2012). Further, studies in the United Kingdom substantiate that migrant social workers often need to complete additional unpaid practicum hours, or accept a less qualified position, in order to acquire local experience (Hussein et al, 2011).

Taken together, these policy-based challenges - immigration, recognition of foreign credentials and securing a license to practice - are experienced as impediments to the movement, settlement and integration of migrant social workers. A heavy onus rests on the social worker to verify that they are a worthy new Canadian, that their social work education is rigourous enough for Canadian expectations, and that they can be reliably granted the social work title in this country.

Through these accounts, we begin to see the internationally famed Canadian welcome begin to tarnish at the edges. Examining a little more closely, we learn that the percentage of immigrants in social work in 2006 was slightly lower than in all occupations: 9\% compared with 12\% (Service Canada, 2013). Unemployment rates for social work are also reportedly low; Service Canada notes that few positions will be filled by unemployed experienced social workers because the jobs are not likely to be available. Auder (2003) theorizes that 'regulatory institutions actively exclude immigrants from the upper segments of the labour market. In particular, professional associations and employers give preference to Canadian born and educated workers and deny immigrants access to the most highly desired occupations' (p. 699). Creese \& Wiebe (2009) question Canadian immigration policies that "prioritize the recruitment of well-educated immigrants without also addressing multiple barriers that exist in the work place" (p. 56). Hence we turn our attention to organizational context, and subsequently, socio-cultural dynamics, to begin to distinguish the discursive from the material in the experiences of migrant social workers.

\subsection{Organizational Context}

After the immigration process, the recognition of international education, and licensing with the provincial regulatory body, migrant social workers are in a position to secure employment in their professional field. Yet organizations and agencies have their own layers of explicit and implicit assessment, providing shape to the experience of newcomer social workers seeking work. In the realm of organizational context we move more into a discursive dimension, where there are as many systemic expectations conveyed through subtle interactions and interpretations as there are formally explicated through the official hiring practices and human resources procedures of particular agencies. The following participants articulate this issue:

The most difficult thing was not having any network. (New Zealand)

How do I put forth my skills and tell 'hey I'm available; I'm available to volunteer; I'm available to give my resources to you'. How do I do that? That is the biggest block I have. (India-1)

... It was difficult to get into social work, even though I have social work experience and my degree is recognized. So after that what did I do is, my wife and I chose, you know what, we need to go back [to the Netherlands] because this is not working in Canada, I can't get a job, proper job, on the level that I had. (Netherlands-2)

The tautological relationship between getting a Canadian job and needing Canadian experience is exemplified here:

...you end up in this vicious circle of you don't have a local experience, right? And you cannot get any experience

here because you don't have a working experience here. Well how can I get it if I don't have a chance? (Ukraine)

This participant from India details his process and strategy of engaging in volunteer work in order to build Canadian experience:

I applied and applied. Nobody was offering me a job. They told me 'you need Canadian experience' and I was asking 'how can I get Canadian experience unless you offer me a job?' So almost six months I sat at home. Then I thought, why should I sit at home? So I went to the hospital and I volunteered for three months....I worked in the Hemodialysis Unit with a great social worker who helped me cope and showed me how I can do things in Canada, how the hospitals are functioning and all that. So I was there with her for 500 hours. (India-1)

Like the participant from the Netherlands cited above, for many of these social workers, migration is not a one-time, one way move. Given the systemic and bureaucratic challenges to securing work, people move to, from, and within Canada due to cumulative stressors. A participant from the US moved to one of the eastern provinces, returned to the US after six months of searching for a job, then took a one-year term position in the Yukon, before settling in the eastern 
province to which he had originally come. Similarly, participants from Finland and Lebanon both went back and forth several times due to financial need, and knowing they could work in their home countries for short periods, earning enough money to then return to Canada to again try to secure long term social work employment. Their stories align with this participant, who kept moving to find work:

We landed to Quebec City and as we all know it's a government city, so I would say all the good jobs were taken by the locals and you know although I look like them, I really, really had a hard time finding employment and I was already bilingual French and English at that time. So we moved to Calgary. (Romania)

The struggle to find work led many to theorize what was happening, questioning why they faced barriers. Some came up with concerns about a paradoxical welcome to this new land:

Not to blow my own trumpet, but I think I have a really good background....from age twenty I've worked in social arenas.... I've done a lot of jobs. And all of them have been working in, you know, kind of oppressed areas or, you know, young people, social justice, always I've worked in that kind of area.... I'm quite surprised that I've never even had an interview, no feedback. And the only deduction I can make, which is obviously not a really good one, is that there is some prejudice against being qualified from another country. (England-3)

This participant theorized the reasons for the challenges she faced in her first Canadian social work job:

The first one is racism, the second one is fear. I have two Masters' degrees and a Bachelor's degree and then I have a boss who has a Certificate of Diplomatic Social Work (sic). So you can imagine what it was like. So I literally lasted one month on that job and I was let go. Yes, because every report I was writing was critically analyzed and scrutinized and someone told me they did not like it. I don't think I do anything wrong. I think I was just doing in something according to my knowledge and my skills. And perhaps she did not understand and she felt threatened you know and so they let me go. (Nigeria)

Organizational contexts structure the realities of employment-seeking in the field of social work in Canada. In the new organizational context, migrant social workers are faced with different types of relations with stakeholders, supervisors, regulators, and colleagues. The participants in this study experienced that they need to work harder than their local counterparts to obtain credibility and/or positioning within the organizational context. This has as much to do with unwritten expectations and understanding of the local context as it does written procedures and site specific policies and laws. We continue to follow the path of the unwritten as we examine the socio-cultural dynamics at play for the participants of this study.

\subsection{Socio-Cultural Dynamics}

Delving into the discursive domain more deeply, participants talked of the struggle to 'fit in' either while looking for social work employment or after they had secured it. Social relations among colleagues and with clients are a central means through which personal and professional adaptation occurs, not only through the translation of skills and knowledge from one's country of origin, but also through figuring out the spoken and unspoken ways of being that are acceptable in the new setting. This participant begins with a global statement Canadians, which she stated 'comes out in a lot of ways':

The Canadian life style, it's completely different than German...they're more laid back I would say in Canada. In Germany we're really strict. (Germany)

The following data excerpts hone in more finely on the ways in which participants feel they had to make adjustments. This social worker names the physical attire changes she needed to make in order to feel responded to in the way she was seeking:

The way I dress has changed. Because of the climate and, ah, because I have to, ah, get along with the people here. Because I just feel that... ah, how to explain it? Like I feel that dressing does give you a different look... It cannot give you a different identity but it does give you a different look.... I feel that it gives confidence. Like if we dress well then people would like to associate with you, they want to be with you. And if you are not, then people distance from you, you know? (India-2)

Proficiency in the primary language of Canada, English, is another area of focus for both personal and professional adaptation, on the professional side likely because social work's central method for intervention relies on the spoken word.

It was a real, real challenge because my language skills were very poor....I didn't feel confident to even start the process of applying for a real job because I was so afraid that I wouldn't be able to communicate....I think it took 2 years to feel that I can really apply for a job with confidence, applying for a job. (Israel)

I spoke not a word in French. My husband told me, 'you have to learn English, because when we arrive, we are 
going in the English side'. Ok fine. So I spoke a little English and, I arrived in Quebec and everyone speaks French, something I did not understand. The 'hello', the 'yes', it was all completely new to me. (Colombia)

For others, proficiency in the language was reportedly fine, however use or tone of the language, or its delivery, was a notable area for attention:

I think my language ability was fairly good already when I came here which helped. I think the barrier was more in sometimes how you say things. People might kind of interpret it in a different way or you use words that in the Netherlands have the same meaning but they don't have the exact same meaning here. (Netherlands-1)

...in my culture, we talk fast and loud and here if you do that people find you aggressive and I try to watch how I talk, how I behave. Sometimes maybe my humor is different. I notice sometimes they don't really understand my jokes so I was like, 'OK, that is not the way how you do it with your co-workers!' (Romania)

Here, a French social worker notes her struggle with the accent and expressions used in Quebec:

The accent! In fact, there is plenty of vocabulary words that are completely different. At the beginning, we don't know them, so if you add a different accent on the top of it, we understand nothing whatsoever. I could only get one every two words! To start with, it is quite funny but then, you begin to find it less and less funny. (France)

From use of language and accents, to manner of interacting, these participants provide examples of comparisons between ways of being in their home countries and in Canada, as does this participant from the US:

I've had to pay attention and be observant of Canadian customs and culture in order to work with Canadian clients. I lived in Washington State so Vancouverites they'd come down and they kind of talked funny, but we just assumed that Western Canadians were just like Americans in everything they do. Then I married a Canadian and came here and Canadians are different than Americans! I have had to back off because Americans are more driven than Canadians. So I back off, I'm not so goal focused....They sit back, they don't move as fast as Americans so I have to take that into my practice and respect that. (United States-3)

In the complexity of adapting the practice of social work to new local contexts, the matter of racism bears particular mention. In this study, social workers of colour face discrimination and Caucasian social workers experience the white privilege that upholds discrimination:

I have to say, just as a comment, and I know it's very sad that I'm saying that, but ...I was lucky that I'm Caucasian. It's very sad for me to tell this. I know that that's a factor in the ability to get a job. It's unfortunate. (Israel)

In Canada discrimination is a huge challenge if you're black from another country. (India-3)

Following a difficult exchange with a co-worker, this participant from Nigeria discussed her impressions with her manager:

...I said, 'it's unfair. I feel unfairly treated. At this point I feel targeted and I feel discriminated against because I'm the only person of color here and I don't think you're giving me the support.' (Nigeria)

A participant from Lebanon explains that while being from a foreign country may not have stopped her getting into a management job, she nevertheless felt she had to do above and beyond to prove her competence. In a meeting, she explains that:

People were asking tough questions, and were tough in the way they were asking questions. I felt my anxiety levels going up and at some point, I had to told myself that I knew well my caseload, and that whatever questions they ask me, I knew my caseload....At the end of the meeting, people were positively impressed by my level of preparation... and it is like they were telling me, 'this one, the Lebanese, she is not too bad' - like if people who come from elsewhere, they were not necessary, good, or able, not necessarily competent.. and that we only employ them because we are trying to get a certain level of equity... in the number of employees [from an ethic minority]. (Lebanon)

Findings of discrimination and racism have been substantiated elsewhere. In the United Kingdom, studies have shown that migrant social workers can be perceived as a less desirable option in recruitment (Hussein et al, 2011; Simpson, 2009). Further, a study conducted in New Zealand reported more than half of the participants had experienced discrimination in the workplace. This discrimination took many forms, such as hostility, humiliation, verbal abuse, sabotage, and devaluation. These realities and the ensuing feeling of exclusion can cause distress, and have been related to the inability to use skills acquired internationally (Fouché, et al, 2013). Moreover, in her study about professional identity in overseas-born social workers in Australia, Harrison (2012) discovered that migrant social workers can perceive a 'glass ceiling effect', experiencing that they are "confined to an 'ethnic sector" due to their identity (p.8). 


\section{Discussion}

Qualitative analysis asks researchers to continually ask the question, 'what is happening here?' exploring the social processes in which the participants are engaged and striving to make meaning of these processes. In this paper we hone in on the material and discursive barriers experienced in the migration of social workers to Canada, which is an expression of the global movement of people and products, trade and technology. Thus we continue to theorize, expanding upon the notion that processes of adaptation and acculturation can be explained 'as an interactional process among one's notions of identity, including professional identity, which involves one's experiences in various social work roles and interventions and the sociocultural and professional environments' (Pullen Sansfaçon et al, 2012: 44). Specifically, here we develop our theorizing to include Bourdieu's notion of cultural capital as a foundation of social life and the basis for one's station in the social order (Bourdieu, 1986).

Bourdieu's conceptualization of capital takes the definition beyond the economic to the cultural, differentiating institutionalized, embodied, and objectified forms as means and ends through which people have greater or lesser access to a particular social class and its privileges of membership (Bourdieu 1986). In this study we can see both institutionalized and embodied cultural capital at work. Institutionalized capital is accrued through immigration status, recognition of academic credentials, and being granted the license to practice social work. These represent the formalized acknowledgment that one's citizenship, education and practice experience have value and accrue authority in the social order and they reflect the neo-liberal priority on optimizing personal productivity in the marketplace. Embodied capital is the cluster of less tangible aspects required to gain entry to the desired social class of the social work practitioner: one's dress, accent, skills, mannerisms, and the more subtle ways people demonstrate they have the resources to meet the expectations to practice in the field. These forms of capital facilitate mobility by enabling access to opportunities and the tools to acquire status and entry to a particular class, that of the social work practitioner in Canada, and thus contribute equally in the construction of the neo-liberal subject who is ready - and responsible - to maximize competitive advantage.

Like economic capital, cultural capital requires an investment and, through a complicated calculation, may promise a profit on that investment (Bourdieu, 1986). This is the negotiation we hear these participants detailing: the ways in which they have invested their time, energy and intellect in their educational pursuits, in their migration, and in their efforts to practice social work in Canada, and they are seeking a return on that investment. Just as financial markets fluctuate based on the decisions of worldwide economic agreements and agents, so too does value in the social market vary and shift based on similarly constructed measures of worth. In other words, there is no inherent and static value system to cultural capital, just as there is not for economic capital: the dominant actors of the (social or financial) market assign the worth of currency, and material and discursive processes scaffold this deliberate decision making. Through the processes of social construction and the hierarchializing of worth, there is differential value placed on some investments and resources more than others, and inequalities in access and opportunity are experienced as a result. Participants in this study are thoroughly concerned about access and opportunity, questioning systems and processes which are promoted as available yet experienced as rife with impediments.

The concept of cultural capital helps explain what is happening for the social workers in this study in a way that simultaneously focuses on individuals while holding to account the social and cultural systems in place which differentially advantage individuals. Thus it has an embedded critique of neo-liberalism's full weight of responsibility resting upon individual success and triumph: what is experienced as an individualized, personalized and barrier-ridden journey can be unpacked to its socially constructed roots, and avenues for advocacy and change emerge. This is important analysis to bring to the current data and the literature on adaptation and acculturation, so often conveyed in individualized ways.

Given this analysis, for example, nation-based standards of accreditation for social work degree programs can be questioned. Specifically, built upon the partnership of the International Association of Schools of Social Work and International Federation of Social Work and the jointly-developed Global Standards document (2012), could educational accreditation be pursued at the international levels, thus eliminating the need for each country to undertake credential recognition? Further, taken from the model of collaboration among these two bodies, perhaps the Canadian Association of Social Workers and provincial regulators could design a single-stop service which would both recognize credentials and grant social work licensure. This possibility seems all the more likely in light of Canadian government policy designed to reduce barriers for interprovincial labour mobility; it could be an extension of the intent, to the international mobility. On the level of socio-cultural and organizational dynamics, we have tools within the profession of social work - analyses of privilege, oppression, exclusion, and domination embedded in systems and visited upon individuals, along with a focus on inherent strengths, resilience, and capacity for change - on which to draw in the effort to strive for congruence between the personal, professional, and political. These are future directions illuminated by the analyses of this research. 


\section{Conclusion}

This paper has reported on the experiences of forty-four social workers who undertook their social work education outside Canada and migrated to Canada intent on continuing to practice social work. Data from this study suggest that migrant social workers are reflecting upon the cultural capital of their ethnic background, social work education and experience, personal and professional identity and comparing it with those desirable in the Canadian market, both economic and social. Their experiences tell stories of a complicated welcome to Canada, challenging the construction upheld by Canadians and others across the world that this is an unequivocal land of opportunity and possibility. Ultimately, these data substantiate the inextricable relationship among personal and professional adaptation, and ascribed value in institutional and embodied capital, articulated well by this participant:

When I start working, I start feeling that I am starting to adapt and to adjust only when I start working. Up until then I was...I knew I didn't want to go back to Israel, but I never felt that Canada is the place for me. So I was really unhappy. But when I start working and being engaged in intellectual aspects of life and with work and being able to perform my skills and to feel valued, I guess, that's where I said 'okay, yeah, Canada is the place I can stay'. So really getting the job in social work, that's what made the difference and just helped me settle in. And I started building my life. (Israel)

\section{References}

Auder, H. (2003). Brain abuse, or the devaluation of immigrant labour in Canada. Antipode, 35(4), 699-717.

Bartley, A., Beddoe, L., Fouché, C., \& Harington, P. (2012). Transnational social workers: Making the profession a transnational professional space. International Journal of Population Research, 1, 1-11.

Beddoe, L., Fouché, C., Bartley, A., \& Harington, P. (2012). Migrant social workers' experience in New Zealand: Education and supervision issues. Social Work Education, 31(8), 1012-1031. http://dx.doi.org/10.1080/02615479.2011.633600.

Bourdieu, P. (1986). The forms of capital. In J. Richardson (Ed.) Handbook of Theory and Research for the Sociology of Education, New York: Greenwood, 241-258.

Canadian Council of Social Work Regulators. (2013). What We Do. http://www.ccswr-ccorts.ca/what_we_do_en.html.

Canadian Information Centre for International Credential. (2007). Mutual Recognition Agreement on Labour Mobility for Social Workers in Canada. http://www.cicdi.ca/docs/mra/social-workers.en.pdf.

Citizenship and Immigration Canada. (2014). The Employer's Roadmap to hiring and retaining internationally trained workers. http://www.statcan.gc.ca/pub/11-402-x/2012000/chap/pop/pop-eng.htm.

Citizenship and Immigration Canada. (2013). Foreign Credentials Referral Office. http://www.cic.gc.ca/english/department/fcro/index.asp.

Creese, G., \& Wiebe, B. (2012). Survival employment: gender and deskilling among African immigrants in Canada. International Migration, 50(5), 56-76. http://dx.doi.org/10.1111/j.1468-2435.2009.00531.x.

Employment and Social Development Canada. (2009). Government of Canada supports labour mobility for social workers. http://www.news.gc.ca/web/article-eng.do?nid=450449.

Employment and Social Development Canada. (2011). Government of Canada Taking Action to Increase Labour Mobility for Social Workers. http://news.gc.ca/web/article-en.do?nid=585829.

Fang, C. (2012). Foreign Credential Assessment and Social Work in Canada. http://www.sasw.ca/council/FQR-Report2012-Final.pdf.

Fouché, C., \& Beddoe, L. (2012). Crossing borders: Migrant social workers as global professionals. In N. Hall (Ed.), Social work around the world V: Building the global agenda for social work and social development, Derbyshire, England: International Federation of Social Workers, 53-64.

Gignac, C. (2013).For Canada, Immigration is a key to Prosperity. The Globe and Mail. http://www.theglobeandmail.com/report-on-business/economy/economy-lab/for-canada-immigration-is-a-key-to-pr osperity/article14711281.d from

Global Standards. (2012). International Association of Schools of Social Work. http://ifsw.org/policies/global-standards.

Gouvernement du Québec (2013), Québec-France Agreement on the Mutual Recognition of professional Qualifications. http://www.mrifce.gouv.qc.ca/en/grands-dossiers/reconnaissance-qualifications/entente-quebec-france.

Harrison, G. (2013). Oh, you've got such a strong accent: Language identity intersecting with professional identity in the human services in Australia. International Migration, Oxford, UK: Blackwell Publishing Ltd., 51(5), 192-204. 
http://dx.doi.org/10.1111/imig.12005.

Healy, K., \& Huegler, N. (2012). International mobility in social work. In K. Healy \& R. Link, (Eds.), Handbook of international social work, Oxford University Press: New York, 487-492.

Hussein, S., Manthorpe, J., \& Stevens, M. (2010). People in places: A qualitative exploration of recruitment agencies' perspectives on the employment of International social workers in the UK. British Journal of Social Work, 40(1), 1000-1016. http://dx.doi.org/10.1093/bjsw/ben131

Hussein, S., Manthorpe, J., \& Stevens, M. (2011). The experiences of migrant social work and social care practitioners in the UK: findings from an online survey. European Journal of Social Work, 14(4), 479-496. http://dx.doi.org/10.1080/13691457.2010.513962

Lyons, K. (2006). Globalisation and social work: International and local implications. British Journal of Social Work, 36(3), 365-80. http://dx.doi.org/10.1093/bjsw/bcl007

Niessen, J., Huddleston, T., Citron, L., Geddes, A., \& Jacobs, D. (2007). Migration Integration Policy Index. http://www.mipex.eu/mipex-archives.

Huddleston, T., Niessen, J, Chaoimh, E. N., \& White, E. (2011). Migration Integration Policy Index III. http://www.mipex.eu/download.

Organization for Economic Cooperation and Development. (2013). International Migration Outlook. http://dx.doi.org/10.177/migr_outlook-2013-en.

Pullen-Sansfaçon, A., Brown, M., \& Graham, J. (2012). International migration of professional social workers: Toward a theoretical framework for understanding professional adaptation processes. Social Development Issues, 34(2), $37-50$.

Pullen-Sansfaçon, A., Brown, M., Graham, J., \& Michaud, A. (2014). Adaptation and acculturation: Experiences of internationally educated social workers. Journal of International Migration and Integration, 15(2), 317-300. http://dx.doi.org/10.1007/s12134-013-0288-2

Pullen-Sansfaçon, A. (2010). La migration internationale des travailleurs sociaux : Un survol du contexte et des enjeux pour la formation en service social au Québec. Intervention Numéro Spécial: La formation en travail social, 132(1), 64-74.

Service Canada. (2013). Job Futures Quebec: Social Workers. http://www.servicecanada.gc.ca/eng/qc/job_futures/statistics/4152.shtml.

Simpson, G. (2009). Global and local issues in the training of overseas social workers. Social Work Education: The International Journal, 28(6), 655-67. http://dx.doi.org/10.1080/02615470903027371.

Spolander, G., Pullen-Sansfaçon, A., Brown, M., \& Engelbrecht, L. (2011). Social work education in Canada, England and South Africa: A critical examination of curriculae and programmes. International Social Work, 54(6), 816-31. http://dx.doi.org/10.1177/0020872810389086

Statistics Canada. (2014). Labour force survey estimates (LFS), by sex and age group, seasonally adjusted and unadjusted, monthly. http://www.statscan.gc.ca

Statistics Canada (2012), Population and demography. http://www.statcan.gc.ca/pub/11-402-x/2012000/chap/pop/pop-eng.htm.

White, R. (2006). Opportunities and challenges for social workers crossing borders. International Social Work, 49(5), 629-40. http://dx.doi.org/10.1177/0020872806066765.

\section{$(\mathrm{cc}) \mathrm{BY}$}

This work is licensed under a Creative Commons Attribution 3.0 License. 